Volume 2, Issue 3, December 2020

Journal Homepage: http://pusdikra-publishing.com/index.php/jetl

\title{
Problematika Pelaksanaan Pembelajaran Daring Masa Pandemic Covid-19 di MIN 3 Medan
}

Novita Sari

UIN Sumatera Utara, Medan

Corresponding Author novitasarinovi9988@gmail.com

\section{ABSTRACT}

Penelitian ini bertujuan melihat sejauh mana untuk menyelesaikan Problematika Pelaksanaan Pembelajaran Daring Di MIN 3 Medan. Penelitian ini merupakan penelitian kualitatif deskritif yaitu jenis penelitian data yang objektif dan alami lapangan. Adapun hasil penelitian adalah pelaksanaan pembelajaran daring kurang efektif hal ini dapat dilihat dari hasil penelitian bahwa MIN 3 Medan mengalami hambatanhambatan seperti pelaksanaan pembalajaran daring dengan menggunakan aplikasi WhatsApp, Zoom Meting, YouTube, pembelajaran yang akan dimanfaatkan ketika belajar daring di MIN 3 Medan ini, guru

ARTICLE INFO

Article history:

Received

30 Oktober 2020

Revised

25 November 2020

Accepted

10 Desember 2020
Kata Kunci

How to cite dalam pelaksanaannya memantau bahwa siswa masih menggunakan HP orang tua untuk pembelajaran daring. Sementara proses pembelajaran daring dilakasanakan pagi hari disaat orang tua sudah berangkat kerja, sehingga kebanyakan siswa terlambat mendapatkan informasi dan terlambat menyelesaikan tugasnya. ketidak mampuan orang tua dalam membeli paket kuota internet, kemudian kebijakan pemerintah hanya berupa zoom, sedangkan banyak orang tua siswa masih kebingungan menggunakan aplikasi zoom. Hal inilah yang dialami oleh guru-guru di MIN3 Medan sehingga guru benar- benar berupaya untuk tetap menjalankan pembelajaran daring dengan upaya satu minggu sekali untuk tatap muka. Hambatan, solusi dan harapan dalam pembelajaran dengan menggunakan sistem daring menjadi topik yang menarik dalam masa pandemi Wabah Covid-19 ini. Meski dalam kondisi yang serba terbatas karena pandemic COVID-19 tetapi masih dapat melakukan pembelajaran dengan cara daring. Orang tua harus menambah waktu untuk mendampingi anak- anak. Sedangkan dari segi guru, guru menjadi melek teknologi dan dituntut untuk belajar banyak hal kususnya pembelajaran berbasis daring. Sistem pembelajaran daring ini dapat dijadikan kualitas kemampuan teknologi guru.

Covid-19, Zoom, Daring, Teknologi.

Novita Sari, (2020). Problematika Pelaksanaan Pembelajaran Daringmasa Pandemic Covid-19 di MIN 3 Medan. Jurnal Journal of Education and Teaching Learning (JETL).

\section{PENDAHULUAN}

Saat ini dunia dikejutkan dengan mewabahnya suatu penyakit yang disebabkan oleh virus yang bernama corona tau dikenal dengan COVID-19. Virus yang disinyalir mulai mewabah 31 Desember 2019 di Kota Wuhan Provinsi Hubei Tiongkok, saat ini menyebar hampir ke seluruh dunia dengan sangat cepat, sehingga WHO menetapkan wabah ini sebagai pandemi global. 
Virus Corona adalah keluarga besar virus yang menyebabkan penyakit mulai dari gejala ringan sampai berat. Diketahui ada dua jenis virus corona yang menyebabkan dan menimbulkan penyakit gejala berat seperti Middle East Respiratory Syndrome (MERS) dan Severe Acute Respiratory Syndrome (SARS). Coronavirus Disease 2019 (Covid-19) adalah penyakit jenis baru yang belum pernah diidentifikasi sebelumnya pada manusia. Virus penyebab Covid-19 ini dinamakan Sars-CoV-2. Virus corona adalah zoonosis (ditularkan antara hewan dan manusia). Penelitian menyebutkan bahwa SARS ditransmisikan dari kucing luwak (civet cats) ke manusia dan MERS dari unta ke manusia. Adapun, hewan yang menjadi sumber penularan Covid-19 ini sampai saat ini masih belum diketahui.

Kebijakan sosial distancing berakibat fatal karena roda kehidupan manusia masalah ekonomi yang paling terasa dampaknya. Tanpa terkecuali pada bidang pendidikan Sistem KBM yang awalnya tatap muka secara langsng kini telah berubah menjadi sistem tatap muka secara daring. Ini menghilangkan tranfer of value dari guru ke peserta didik. Namun, kondisilah yang meminta

Permasalahan dan solusi sistem pendidikan Indonesia masa pandemic covid-19. Pada tahun 2020 ini, siapa sangka virus covid-19 ini, muncul. Sistem pendidikan di Indonesia biasanya dilakukan langsung atau tatap muka dan sekarang digantikan dengan cara belajar online, atau sering kita sebut daring. Hal ini, adalah dampak dari virus covid-19 ini, Pendidikan ini, mempunyai peran yang penting dalam mengembangkan generasi kita. Jadi tujuan pendidikan di Indonesia adalah untuk mengembangkan potensi peserta didik agar menjadi manusia yang beriman dan bertakwa terhadap Tuhan Yang Maha Esa, berakhlak mulia, sehat, berilmu, cakap, kreatif, mandiri dan menjadi warga Negara yang demokratis serta bertanggung jawab.

Pembelajaran ini mengakibatkan menurunnya kualitas pendidikan Pembelajaran secara daring, bekerja dari umah, lemahnya tingkat pemahaman anak,sulit mendisiplinkan anak, banyak wilayah yang sulit terjangkau jaringan ,kurangnya kesabaran orang tua dalam membimbing anak bertolak dari pemikiran tersebut maka peneliti ingin melihat sejauh mana untuk menyelesaikan Problematika Pelaksanaan Pembelajaran Daring Di MIN 3 Medan.

\section{METODOLOGI PENELITIAN}

Penelitian ini merupakan penelitian kualitatif deskritif yaitu jenis penelitian data yang objektif dan alami lapangan. Menurut Bog dan Taylor, metode kualitatif adalah prosedur penelitian yang menghasilkan data deskriptif berupa kata-kata tertulis atau lisan dari orang-orang dan perilaku yang diamati. 
Pendekatan penelitian kualitatif adalah proses penelitian yang menghasilkan data deskriptif berupa kata-kata tertulis atau lisan dari orangorang dan perilaku yang dapat diamati. oleh karena itu, penelitian ini menggunakan metode deskriptif. Jadi jenis penelitian ini memahami pendekatan kualitatif karena melalui pendekatan tersebut lebih tepat untuk mengindentifikasi penilaian kinerja guru dalam meningkatkan profesionalisme guru di MIN 3 Medan. Adapun teknik pengumpulan data yang digunakan seperti observasi, interview dan dokumentasi. Untuk pengujian keabsahan data dilakukan dengan triangulasi data

\section{HASIL DAN PEMBAHASAN}

\section{Problematika Pembelajaran Daring di Masa Pandemik}

Problematika, dalam KBBI diartikan hal yang menimbulkan masalah: hal yang belum dapat dipecahkan: permasalahan.

(Daulay, 2016) Menyebutkan problematika dalam dapat diartikan:

1. Ketidak sesuaian antara yang seharusnya dan kenyataan.

2. Segala hambatan yang dialami oleh guru dalam pendidikan untuk tercapainya tujuan pendidikan.

Pelaksanaan pembelajaran daring bukan tanpa masalah, dilaporkan bahwa di antara mereka yang mengadopsi pembelajaran daring, rata-rata manfaat sebenarnya jauh lebih kecil daripada yang diharapkan. Masalah jaringan, kurangnya pelatihan, dan kurangnya kesadaran dinyatakan sebagai tantangan utama yang dihadapi oleh pendidik. Kurangnya kesadaran dinyatakan sebagai alasan paling penting oleh mereka yang tidak mengadopsi pembelajaran daring diikuti oleh kurangnya minat dan keraguan tentang kegunaan pembelajaran daring. Kurang kehadiran, kurangnya sentuhan pribadi, dan kurangnya interaksi karena masalah konektivitas ditemukan menjadi kelemahan signifikan dari pembelajaran daring. Menurut $M$. Wahyudi, fakta di lapangan, kewajiban belajar di rumah menjadi kendala serius khususnya peserta didik dari kalangan yang kurang beruntung secara ekonomi. Mereka sering mengeluhkan habisnya paket kuota internet. Selain itu, teknologi dianggap dapat membangun sikap instan bagi para penggunanya. Menurut Tim Kompas, laporan dari sejumlah daerah di Indonesia menunjukkan bahwa penerapan pembelajaran daring belum berjalan optimal, terutama di daerah pelosok dengan teknologi dan jaringan internet terbatas. Gambar 2 menunjukkan bahwa pada tahun 2018 saja secara nasional hanya $39,90 \%$ penduduk yang mengakses internet. Kesiapan infrastruktur sekolah, kemampuan guru mengajar secara daring, serta ketersediaan sarana 
smartphone menjadi persoalan lain dalam penerapan pembelajaran daring di Indonesia.

Kebijakan belajar dari rumah telah merubah pola belajar para siswa dan mahasiswa. Hal ini tentu disecara langsung bisa berjalan dengan baik, karena selama ini telah terbiasa belajar secara tatap muka. Menurut Husamah (2015) secara umum, pembelajaran tatap muka memiliki berbagai kelebihan terhadap pengajar maupun peserta didik, antara lain: 1. Disiplin formal yang diterapkan pada pembelajaran tatap muka dapat membentuk disiplin mental; 2. Memudahkan pemberian penguatan (reinforcement) dengan segera; 3. Memudahkan proses penilaian oleh pengajar; 4. Menjadi wahana belajar berinteraksi terhadap peserta didik. Kelebihan lainnya yaitu kemampuan sosialisasi antara dosen/tutor dengan mahasiswa, maupun antar sesama teman. Tidak hanya itu saja, dosen dapat mengamati secara langsung sikap dan tingkah laku mahasiswa dalam menerima materi. Walaupun terdapat berbagai kelebihan, namun pandemic Covid-19 ini memaksa semua guru dan dosen harus melakukan aktivitas belajar mengajar melalui pembelajaran dalam jaringan (Daring). Pembelajaran daring ini sendiri membutuhkan kreativitas dan inovasi dari para pendidik, sehingga pembinaan, transfer pengetahuan dan keterampilan dapat berjalan dengan baik. Semua pendidik harus menguasai komunikasi dalam jaringan, yakni cara berkomunikasi yang di mana cara penyampaian dan menerima pesan yang dilakukan melalui jaringan internet. Dengan munculnya pandemik COVID-19 kegiatan belajar mengajar yang semula dilaksanakan di sekolah kini menjadi belajar di rumah melalui daring. Pembelajaran daring dilakukan dengan disesuaikan kemampuan masingmaisng sekolah. Belajar daring (online) dapat menggunakan teknologi digital seperti google classroom, rumah belajar, zoom, video converence, telepon atau live chat dan lainnya. Namun yang pasti harus dilakukan adalah pemberian tugas melalui pemantauan pendampingan oleh guru melalui whatsapp grup sehingga anak betul-betul belajar. Kemudian guru-guru juga bekerja dari rumah dengan berkoordinasi dengan orang tua, bisa melalui video call maupun foto kegiatan belajar anak dirumah untuk memastikan adanya interaksi antara guru dengan orang tua (Dewi, 2020). Menurut Setyosari (2015) pembelajaran daring memiliki potensi-potensi, antara lain: kebermaknaan belajar, kemudahan mengakses, dan peningkatan hasil belajar. Dalam konteks belajar secara online, mahasiswa dapat berhubungan secara cepat dan langsung dengan teks, gambar, suara, data, dan video dua arah, dengan bimbingan pengajar. Tutorial tatap muka diganti

Pembelajaran Dalam Jaringan dan Upaya Memutus Pandemi Covid-19 dengan perantara teknologi yang disebut tuweb diharapkan hasil belajar 
mahasiswa menjadi bagus di tengah maraknya virus covid-19. Proses belajar dan mengajar dengan bantuan teknologi, diharapkan menghasilkan prestasi yang meningkat, karena tidak hanya penguasaan materi melainkan juga menguasai teknologinya. Disatu sisi inovasi yang berbentuk metode dapat berdampak pada perbaikan, meningkatkan kualitas pendidikan serta sebagai alat atau cara baru dalam memecahkan masalah yang dihadapi dalam kegiatan pendidikan. Dengan demikian metode atau cara baru dalam melaksanakan metode yang ada seperti dalam melakukan proses pembelajaran dapat menjadi suatu upaya meningkatkan efektivitas pembelajaran. Dan dukungan teknologi informasi dalam suatu inovasi pembelajaran perlu diperhatikan karena dapat digunakan untuk lebih meningkatkan kualitas pendidikan itu sendiri (Sudrasana, 2020).

Dalam pembelajaran daring ini, MIN 3 Medan juga mengalami suatu permasalahan atau problem, sebagaimana peneliti mewawancari salah satu guru kelas rendah, ia mengatakan bahwa problem yang saat ini di alami yaitu:

1. Kurangnya kedisiplinan anak

2. Kurangnya kemampuan anak dalam mencapai materi, sebab banyak orang tua yang mengeluh karena tidak kemampuan dalam membimbing anak.

3. Lemahnya tingkat pemahaman anak, sebab tidak adanya interaksi guru.

\section{Kepemimpinan Kepala Sekolah Dalam Peningkatan Kerja Guru di Masa Pandemik}

Di dalam sebuah organisasi pemimpin adalah sebagai komunikator. Pemimpin yang efektif pada umumnya memiliki kemampuan komunikasi yang efektif sehingga sedikit banyak akan mampu merangsang partisipasi orangorang yang dipimpinnya. Dia juga harus piawai dalam melakukan komunikasi. Tujuan dan manfaat komunikasi adalah sebagagai sarana untuk, meningkatkan kemampuan manajeial dan hubungan social, menyampaikan atau menerima informasi, menyampaikan dan menjawab pertnyaan, mengubah perilaku (pola piker, perasaan, dan tindakan) melalui perencanaan pengorganisasian, pengarahan motvasi, koordinaso, dan pengawassan, mengubah keadaan social, dapat mengubah perilaku dan keadaan social adalah komunikasi dan pengambilan keputusan (Usman, 2006).

Kepimpinan yang efektif juga dapat diartikan sebagai kemampuan untuk memimpin agar mendapat performa yang tinggi dari bawahannya. Aktivitas kepemimpinan bagian dari kegiatan yang dilakukan oleh pemimpin dan manajer dalam organisasi. Banyak menggerakkan organisasi, sehingga mencapai tujuan, target dan sasaran secara efektif. Peran manajer sebagai 
pemimpin dapat bermacam-macam antara lain, memberi, imbalan melimpahkan wewenang, mempercayai bawahan dan memberikan penghargaan (Sagala, 2018).

Menurut (Herdah, 2020) Kompetensi guru dalam memanfaatkan teknologi dan menguasai teknologi untuk pembelajaran dituntut untuk meningkat dengan cepat merespon online Home learning. Dalam hal ini kinerja gurulah yang paling ditingkatkan untuk menjalankan pembelajaran dimasa pandemic. Kinerja atau sering di kenal dengan performance adalah tentang bagaimana mengelola kegiatan dalam suatu organisasi untuk mencapai tujuan organisasi. Keberhasilan dan kesesuksesan kinerja ditentukan oleh kualitas pimpinan dan guru, sehingga pemahaman dan kemampuan dalam mengoperasikan dengan kinerja menjadi suatu kebutuhan sehingga dapat berhasil guna dan berdaya guna. Kinerja adalah tentang melakukan pekerjaan dan hasil yang dicapai dari pekerjaan tersebut. Dan kinerja tentang apa yang dikerjakan dan bagaimana cara mengerjakannya (Wibowo, 2017).

Upaya yang dilakukan oleh pemimpin atau kepala sekolah MIN 3 Medan dalam semangat kinerja guru pada masa pendemik dapat dilaksanakan dengan beberapa langkah:

1. Membuat Tim Kinerja untuk membentuk roster dimasa pandemic

2. Menentukan Jadwal pertemuan kepada guru untuk melihat hasil kinerja gurunya dalam 1 kali seminggu.

3. Berkomunikasi dengan baik terhadap guru- guru agar guru paham dalam mencapai untuk tujuan Memotivasi guru dalam penerapan pembelajaran daring.

\section{Pelaksaaan Pembelajaran Daring di Masa Pandemik}

Pembelajaran merupakan kegiatan yang didalam pelaksanaannya melibatkan guru dan siswa. Pelaksanaan pembelajaran yaitu kemampuan guru dalam mendayagunakan sumber daya yang ada, melalui kegiatan menciptakan dan mengembangkan kerja sama, sehingga diantaranya akan tercipta pembelajaran dalam mencapai tujuan pendidikan secara efektif dan efesien.

Lebih lanjut menurut Muslich dalam (Kresnawaty dan Mulyadi, 2020), secara teknis pelaksanaan kegiatan pembelajaran atau KBM menampakkan pada beberapa hal, yaitu pengelolaan tempat belajar/ ruang kelas, pengelolaan bahan pelajaran, pengelolaan kegiatan dan waktu, pengelolaan siswa, pengelolaan sumber belajar dan pengelolaan perilaku mengajar.

Menurut Isman, pembelajaran daring merupakan pemanfaatan jaringan internet dalam proses pembelajaran. Dengan pembelajaran daring siswa memiliki keleluasan waktu belajar, dapat belajar kapanpun dan dimanapun. 
Siswa dapat menggunakan beberapa aplikasi seperti classroom, video converence, zoom maupun whatshapp group (Fatma 2020).

Salah satu dampak social distancing juga terjadi pada sistem pembelajaran di sekolah. Berdasarkan Surat Edaran Nomor 4 Tahun 2020 tentang Pelaksanaan Kebijakan Pendidikan dalam masa darurat penyebaran virus, Mendikbud menghimbau agar semua lembaga pendidikan tidak melakukan proses belajar mengajar secara langsung atau tatap muka, melainkan harus dilakukan secara tidak langsung atau jarak jauh Dengan adanya himbauan tersebut membuat semua lembaga pendidikan mengganti metode pembelajaran yang digunakan yaitu menjadi online atau dalam jaringan (daring).

Belajar daring (online) dapat melalui media juga seperti teknologi digital, google classroom, rumah belajar, zoom, video converence, telepon atau live chat dan lainnya. Namun yang pasti harus dilakukan adalah pemberian tugas melalui pemantauan pendampingan oleh guru melalui whatsapp grup sehingga anak betul-betul belajar. Kemudian guru-guru juga bekerja dari rumah dengan berkoordinasi dengan orang tua, bisa melalui video call maupun foto kegiatan belajar anak dirumah untuk memastikan adanya interaksi antara guru dengan orang tua.

Pembelajaran dengan menggunakan teknologi baru memang telah berjalan selama beberapa dekade. Akan tetapi, dapat dikatakan bahwa dampak transformational sebagaimana yang diharapkan belum tercapai. Sehubungan dengan itu, peralihan ke pembelajaran daring tentu saja bukanlah solusi yang benar-benar sempurna.

Pada tanggal 24 maret 2020 Menteri Pendidikan dan Kebudayaan Republik Indonesia mengeluarkan Surat Edaran Nomor 4 Tahun 2020 Tentang Pelaksanaan Kebijakan Pendidikan Dalam Masa Darurat Penyebaran COVID, dalam Surat Edaran tersebut. Kebijakan belajar dari rumah telah merubah pola belajar para siswa. Hal ini tentu secara langsung tidak bisa berjalan dengan baik, karena selama ini telah terbiasa belajar secara tatap muka.

Keadaan ini tentu saja memberikan dampak pada kualitas pembelajaran, siswa dan guru yang sebelumnya berinteraksi secara langsung dalam ruang kelas sekarang harus berinteraksi dalam ruang virtual yang terbatas. guru dituntut memberikan pengajaran yang baik, menciptakan suasana yang kondusif untuk belajar dan secara kreatif dan inovatif, menggunakan media belajar yang menarik agar siswa dapat memahami materi pembelajaran dan tujuan pembelajaran dapat tercapai. Dengan munculnya pandemik COVID-19 kegiatan belajar mengajar yang semula dilaksanakan di sekolah kini menjadi belajar di rumah melalui daring. Sebagaimana yang telah dilaksanakan sekolah 
MIN 3 Medan untuk dapat terlaksana tujuan pendidikan maka langkah pembelajaran daring tetap terlaksanakan dengan menggunakan metode.

Adapun metode - metode yang dilakukan oleh guru-guru MIN 3 Medan yaitu:

1. Membuat Roster Pelajaran yang lebih sederhana dengan penyajian setiap mata pelajaran hanya diberikan 1 kali pertemuan dalam 1 minggu dengan limit waktu yang terbatas.

2. Menyajikan pembelajaran yang mengarah pada ketercapaian kompetensi inti saja.

3. Lebih ditekankan pada pembelajaran penanaman akhlak seperti pembiasaan dalam melaksanakan sholat dhuha dan bertadarus sebelum memulai pembelajaran.

\section{Hambatan Hambatan Pembelajaran Daring Bagi Guru}

Iklim belajar yang diciptakan pembelajaran daring turut mempengaruhi motivasi belajar siswa, jika dalam pembelajaran luring guru mampu menciptakan suasana kelas kondusif maka hasilnya hal ini guru tidak kesulitan dalam memberi penilaian. untuk menjaga suasana yang kondusi guru harus mampu memberikan: motivasi belajar, kedisiplinan, siswa agar pembelajaran dapat tercapai karena iklim kelas memiliki pengaruh yang signifikan dengan motivasi belajar. Namun kondisi pembelajaran daring menyebabkan guru kesulitan untuk mengontrol dan menjaga iklim belajar karena terbatas dalam ruang virtual. Kondisi ini menyebabkan motivasi belajar siswa dapat menurun bahkan mempengaruhi hasil belajar siswa.

Proses pembelajaran dari rumah melalui Pembelajaran jarak jauh idealnya tetap dapat mengakomodasi kebutuhan belajar siswa untuk mengembangkan bakat dan minat sesuai dengan jenjang pendidikannya. Untuk mewujudkan hal tersebut diperlukan kesiapan pendidik, kurikulum yang sesuai, ketersediaan sumber belajar, serta dukungan peranti dan jaringan yang stabil sehingga komunikasi antar peserta didik dan pendidik dapat efektif. Kondisi pembelajaran jarak jauh saat ini belum dapat disebut ideal sebab masih terdapat berbagai hambatan yang dihadapi. Hambatan tersebut sekaligus menjadi tantangan dalam pelaksanaan pembelajaran jarak jauh mengingat pelaksanaan pembelajaran jarak jauh merupakan keharusan agar kegiatan pendidikan tetap dapat terselenggara di tengah darurat pandemi Covid-19 yang terjadi saat ini. Hambatan yang dihadapi dalam pelaksanaan pembelajaran jarak jauh antara lain berkaitan dengan kesiapan sumber daya manusia (Arifa, 2020).

Pendidikan saat ini sedang berupaya untuk menyelesaikan masalah yang ada pada saat ini, seperti munculnya pembelajaran daring yang harus 
dilaksanakan sesuai dengan surat edaran. Namun demikian sekolah MIN 3 tidak menutupi kemungkinan munculnya suatu problem dalam pembelajaran daring. Hal ini dapat dilihat dari hasil wawancara yang dilakukan oleh peneliti bersama ibu Mawar S.PdI dalam sebuah wawacara yang dilakukan di sekolah MIN 3 Medan pada pukul 09.20 wib, bahwa pembelajaran daring ini kurang efektif apabila dibandingkan dengan pembelajaran tatap muka langsung, karena adanya hambatan- hambatan yang dihadapi dalam pembelajaran daring seperti:

- Siswa masih menggunakan HP orang tua untuk pembelajaran dring. Sementara proses pembelajaran daring dilakasanakan pagi hari disaat orang tua sudah berangkat kerja, sehingga kebanyakan siswa terlambat mendapatkan informasi dan terlambat menyelesaikan tugasnya.

- Ketidak mampuan orang tua dalam membeli paket kuota internet.

- Kebijakan pemerintah hanya berupa zoom, sedangkan banyak orang tua siswa masih kebingungan menggunakan aplikasi zoom.

Hal ini sejalan dengan hasil penelitian Purwanto et al: yaitu terdapat beberapa kendala yang dialami oleh murid, guru dan orang tua dalam kegiatan belajar mengajar daring yaitu penguasaan teknologi masih kurang, penambahan biaya kuota internet, adanya pekerjan tambahan bagi orang tua dalam mendampingi anak belajar, komunikasi dan sosialisasi antar siswa, guru, dan orang tua menjadi berkurang dan Jam kerja yang menjadi tidak terbatas bagi guru karena harus berkomunikasi dan berkoordinasi dengan orang tua, guru lain, dan kepala sekolah.

Selain itu, menurut Anugrah (2020) seiring perjalanan waktu muncul banyak permasalahan dalam implementasi pembelajaran daring. Di antara permasalahan itu adalah tugas guru yang terlalu banyak dan keluhan soal kuota dan jaringan internet yang serba terbatas. Kondisi tersebut sejalan dengan hasil riset Kementerian Pemberdayaan Perempuan dan Perlindungan Anak pada bulan Maret 2020 dengan subyek peserta didik usia 14-17 tahun (69\% perempuan dan 31\% laki-laki) berjumlah 717 dari 29 provinsi di seluruh Indonesia. Hasil menunjukkan bahwa $58 \%$ peserta didik tidak suka menjalani program belajar dari rumah. Faktor penyebabnya adalah peserta menganggap bahwa komunikasi dengan teman menjadi terbatas, mereka mengalami keterbatasan teknologi: berupa fasilitas internet, gawai, dan buku elektronik. Mereka juga mengangap bahwa sekolah tidak memiliki program yang baik untuk sistem belajar di rumah. Sekolah dan guru hanya memberi tugas secara beruntun sesuai rencana pelajaran dan materi pelajaran dalam kondisi nonpandemi/kondisi biasa. 


\section{Kelebihan dan Kelemahan Pembelajaran Daring}

\section{Kelebihan Pembelajaran Daring}

Peran Orang Tua dalam Konsep “Belajar di Rumah” Adanya kebijakan "Belajar di Rumah" menyebabkan peran orang tua dalam proses pembelajaran menjadi sangat vital. Kontribusi orang tua berlipat ganda yaitu selain sebagai orang tua siswa juga sebagai guru. Berkaitan dengan peran orang tua dalam konsep "Belajar di Rumah" adalah sebagai berikut : 1. Membantu dalam mengembangkan potensi dan kreativitas anak. Dengan adanya kebijakan "Belajar di Rumah" maka waktu orang tua bersama dengan anak akan semakin banyak. Momentum ini dapat dimanfaatkan oleh orang tua dalam mengembangkan kreativitas anak yang berkaitan dengan IPA. 2. Menjadi teladan (role model). Anak usia SD belajar dengan konsep meniru apa yang dilakukan oleh orang-orang di sekitarnya termasuk orang tuanya. Oleh karena itu, orang tua diharapkan bisa menjadi teladan bagi anak-anaknya. Misalnya, memberikan contoh dalam mendemonstrasikan percobaan IPA yang bisa dilakukan di rumah serta mendampingi anak ketika belajar. 3. Sebagai motivator. Orang tua harus mampu memotivasinya anakanaknya agar bersemangat dalam belajar selama di rumah. 4. Sebagai fasilitator. Orang tua diharapkan mampu memfasilitasi anak jika mengalami kesulitan belajar sesuai dengan kemampuan yang dimiliki oleh orang tua. 5. Sebagai pengawas. Selama kebijakan 'Belajar di Rumah", orang tua diharapkan mengawasi anak dalam belajar misalnya mengingatkan anak untuk mengerjakan tugas yang diberikan guru dan menegur anak jika lalai terhadap waktu belajar. 6. Sebagai evaluator. Jika orang tua memiliki kemampuan, orang tua bisa mengevaluasi belajar anak. Misalnya memeriksa tugas yang telah dikerjakan oleh anak, menanyakan ulang hal yang telah dipelajari anak serta mengajak anak berdiskusi terkait hal tersebut (Wijaya, (2020).

Dari hasil penelitian, peneliti juga bertanya tentang kelebihan pembelajaran dimasa pandemic covid 19. Ternyata kelebihannya dapat dipantau oleh guru bahwasannya orang tua murid bisa selalu mendukung dan bekerja sama dalam pembelajaran daring untuk mnyelesaikan sebuah eksperimen seperti dalam pembelajarang kesenian, hal ini dapat terlihat bahwa orang tua mampu mewujudkan akhir dari pembelajaran yang di inginkan. Hal ini dapat terlihat dalam video yang terkirim untuk menyelesaikan pelajaran kesenian, dalam video itu berdurasi kurang lebih 8 menit, orang tua bekerja sama membuat sebuah eksperimen dengan Menggunakan alat-alat yang ada di Rumah. 


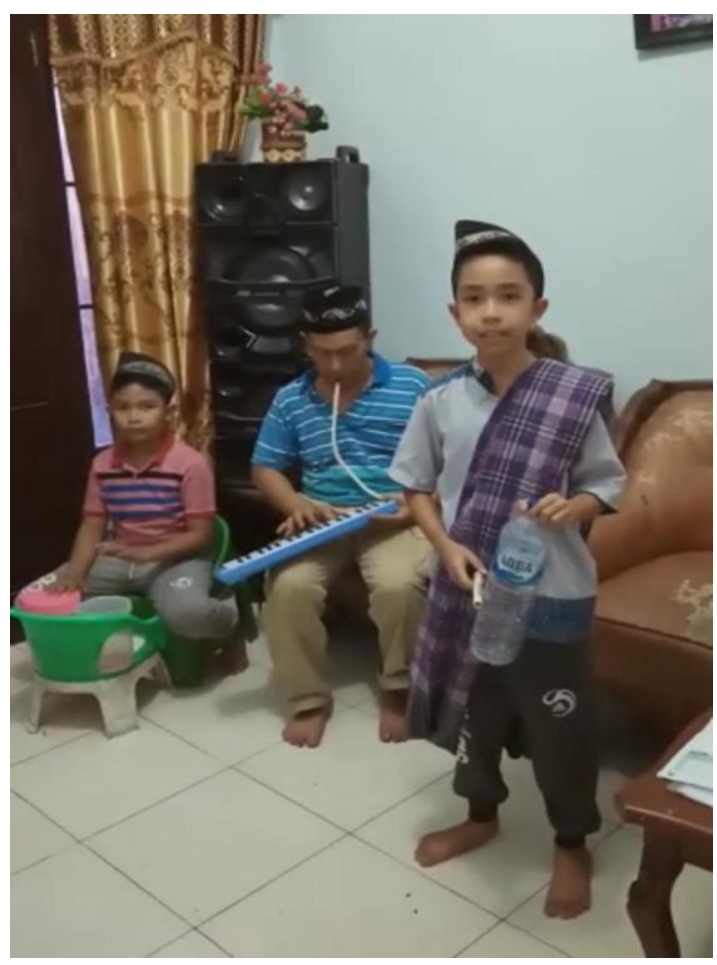

(Emalfida, dkk. 2020) menyatakan bahwa kelebihan menurut Pembelajaran secara daring memiliki kelebihan diantaranya:

a. Pengajar dan siswa dapat berkomunikasi secara mudah melalui internet secara kapan saja kegiatan berkomunikasi itu dilakukan tanpa dibatasi oleh jarak, tempat, dan waktu.

b. Pengajar dan siswa dapat menggunakan bahan ajar yang teratur dan terjadwal melalui internet.

c. Siswa dapat mengulang materi setiap saat dan dimana saja apabila diperlukan. Siswa akan lebih mudah mendapatkan tambahan informasi yang berkaitan dengan bahan ajar yang dipelajarinya dengan mengakses internet.

d. Pengajar maupun siswa dapat melakukan diskusi melalui internet yang bisa diikuti dengan jumlah siswa yang banyak.

e. Siswa yang pasif bisa menjadi aktif.

f. Pembelajaran menjadi lebih efisien karena dapat dilakukan kapan saja dan dimana saja terutama bagi mereka yang tempat tinggalnya yang lebih jauh

\section{Solusi Pemecahan Pembelajaran Daring di Masa Pandemik}

Pembelajaran daring ini sendiri membutuhkan kreativitas dan inovasi dari para pendidik, sehingga pembinaan, transfer pengetahuan dan keterampilan dapat berjalan dengan baik. Semua pendidik harus menguasai komunikasi 
dalam jaringan, yakni cara berkomunikasi yang di mana cara penyampaian dan menerima pesan yang dilakukan melalui jaringan internet.

Peneliti mengemukakan bahwa pelaksanaan pembelajaran daring memiliki tujuan utama yaitu: mempertahankan kualitas pengajaran sebanyak dan menyelesaikan semester dengan baik. Hal ini dapat dilakukan dengan:

1. Mulailah dengan memberi penugasan selama beberapa minggu mendatang. Apakah materi dapat disampaikan secara daring, sehingga siswa dapat menemukan instruksi dan materi yang mereka butuhkan,

2. guru akan memberi umpan balik tentang kemajuan peserta didik, mempertimbangkan bagaimana peserta didik akan dapat mempraktikkan keterampilan dan tujuan utama yang diharapkan.

3. Guru memberi peserta didik kesempatan untuk latihan dan umpan balik, untuk penugasan kecil Tidak diragukan lagi peluang itu akan berbeda dari sebelumnya sebelum guru memindahkan kelas secara daring.

4. meningkatkan aspek pembelajaran-mengingat guru tidak akan menyajikan konten secara langsung.

5. Memberi materi yang tidak membuat jenuh seperti presentasi konten, memeriksa pemahaman,

6. mempertimbangkan materi yang akan diberikan. Kemungkinan, bacaan dan materi lainnya ada dalam bentuk digital, dan guru mungkin sudah mempostingnya. Tetapi guru harus memeriksa ulang apakah bacaan, video, kumpulan masalah, kuis, dan sejenisnya dapat diakses, bersama dengan dokumen-dokumen utama seperti silabus dan jadwal.

7. Setelah guru memeriksa hal-hal tersebut, maka pastikan semua terkomunikasikan dengan baik.

Dalam kaitan ini Guru perlu menjelaskan sedetail mungkin apa yang dapat diharapkan dari peserta didik tentang pembelajaran daring dalam beberapa minggu ke depan. Pastikan untuk membahas apa yang menjadi tanggung jawab peserta didik untuk dilakukan, bagaimana mereka dapat menemukan hal-hal yang mereka butuhkan untuk memenuhi tanggung jawab itu, dan apa yang harus mereka lakukan terlebih dahulu. Pastikan juga jalur komunikasi dua arah, tawarkan lebih banyak cara untuk berkomunikasi dengan guru. Hal lain yang tidak kalah pentingnya adalah saat ini dibutuhkan kurikulum yang fleksibel dan siap menghadapi pandemi. Menurut Wangi (2020), Kurikulum 2013 yang berlaku saat ini di Indonesia tidak dirumuskan untuk menghadapi pandemi COVID-19 di tahun 2020. Padahal bangsa ini 
membutuhkan kurikulum yang fleksibel. Indonesia juga membutuh skenario pembelajaran (silabus, lesson plan) yang fleksibel, dan multi-skenario pembelajaran.

Dalam hal ini penulis juga memberikan solusi agar pembelajaran daring di masa pandemic ini juga dibuthkan:

- Kreativitas dan inovasi dari para pendidik, sehingga pembinaan, transfer pengetahuan dan keterampilan dapat berjalan dengan baik

- Semua pendidik harus menguasai komunikasi yang efektif dalam jaringan, yakni cara berkomunikasi yang dimana cara penyampaian dan menerima pesan yang dilakukan melalui jaringan internet

- apresiasi terhadap capaian siswa perlu diberikan kepada guru agar tujuan pembelajaran bisa tercapai dengan sesuai visi dan misi, salah satu tujuan pemebelajaran termasuk dalam hal ini pembelajaran daring adalah pencapaian kompetensi peserta didik yang dikenal

\section{KESIMPULAN}

Berdasarkan hasil penelitian tentang problematika yang dihadapi guru dalam pembelajaran mengajar daring pada masa pandemi Covid-19 di MIN 3 Medan dapat disimpulkan bahwa pelaksanaan pembelajaran daring kurang efektif hal ini dapat dilihat dari hasil penelitian bahwa MIN 3 Medan mengalami hambatan- hambatan seperti pelaksanaan pembalajaran daring dengan menggunakan aplikasi WhatsApp, Zoom Meting, YouTube. Berkaitan dengan pembelajaran yang akan dimanfaatkan ketika belajar daring di MIN 3 Medan ini, guru dalam pelaksanaannya memantau bahwa siswa masih menggunakan HP orang tua untuk pembelajaran daring. Sementara proses pembelajaran daring dilakasanakan pagi hari disaat orang tua sudah berangkat kerja, sehingga kebanyakan siswa terlambat mendapatkan informasi dan terlambat menyelesaikan tugasnya, ketidak mampuan orang tua dalam membeli paket kuota internet, kemudian kebijakan pemerintah hanya berupa zoom, sedangkan banyak orang tua siswa masih kebingungan menggunakan aplikasi zoom. Hal inilah yang dialami oleh guru-guru di MIN3 Medan sehingga guru benar- benar berupaya untuk tetap menjalankan pembelajaran daring dengan upaya satu minggu sekali untuk tatap muka.

Hambatan, solusi dan harapan dalam pembelajaran dengan menggunakan sistem daring menjadi topik yang menarik dalam masa pandemi Wabah Covid-19 ini. Meski dalam kondisi yang serba terbatas karena pandemic COVID-19 tetapi masih dapat melakukan pembelajaran dengan cara daring. Orang tua harus menambah waktu untuk mendampingi anak- anak. Sedangkan dari segi guru, guru menjadi melek teknologi dan dituntut untuk 
belajar banyak hal kususnya pembelajaran berbasis daring. Sistem pembelajaran daring ini dapat dijadikan kualitas kemampuan teknologi guru.

Faktor utama yang lebih penting lagi dalam perkembangan menurunnya karakter peserta didik adalah tingkat kedisipilan anak. Terkait dengan penelitian yang di dapatkan, maka penulis mencoba untuk memberikan beberapa saran diantaranya: Pembelajaran daring ini sendiri membutuhkan kreativitas dan inovasi dari para pendidik, sehingga pembinaan, transfer pengetahuan dan keterampilan dapat berjalan dengan baik. Semua pendidik harus menguasai komunikasi dalam jaringan, yakni cara berkomunikasi yang di mana cara penyampaian guru perlu menjelaskan sedetail mungkin apa yang dapat diharapkan dari peserta didik tentang pembelajaran daring dalam beberapa minggu ke depan. Kemudian pastikan untuk membahas apa yang menjadi tanggung jawab peserta didik untuk dilakukan, bagaimana mereka dapat menemukan hal-hal yang mereka butuhkan untuk memenuhi tanggung jawab itu, dan apa yang harus mereka lakukan terlebih dahulu. Pastikan juga jalur komunikasi dua arah, tawarkan lebih banyak cara untuk berkomunikasi dengan guru.

\section{DAFTAR PUSTAKA}

Haidar Putra Daulay, Pemberdayaan Pendidikan Agama Islam Di sekolah, Kencana : Jakarta (2016),

Husaini usman "Manajemen Teori dan Praktik", Bumi Aksara: yogyakarta (2006)

Ketut Sudarsana, dkk, "Covid 19 Perspektif Alquran" Yayasan Kita Menulis, (2020)

Syaiful Sagala, Pendekatan dan model kepemimpinan, Kencana (2018)

Sima Mulyadi, Anita Kresnawaty, Manajemen Pendidkan Inklusif, Kesatria Siliwangi, (2020)

Edukatif: Jurnal Ilmu Pemdidikan vol 2 No 1 April 2020 p.ISSN 2656-8063, Wahyu Aji Fatma Dewi: dikutip 08/12/2020, pukul: 00.01 wib

Jurnal “Tantangan Pelaksanaan Kebijakan Belajar Dari Rumah Dalam Masa Darurat Covid-19, Fieka Nurul Arifa Vol. XII, No. 7/I/Puslit/April/2020

Jurnal : Pola Pembelajaran IPA Siswa Sekolah Dasar di Era “Belajar di Rumah” I Komang Wisnu Budi Wijaya, dkk

Jurnal "Kendala Yang Dihadapi Guru Mengajar Daring Pada Masa Pandemi Covid19 Di Min 5 Banda Aceh" Contraints Faced By The Princess Teacher : Nindia Taradisa, Nida Jarmita, Emalfida Program Studi Pendidikan Guru Madrasah Ibtidaiyah, Fakultas Tarbiyah.

Jurnal :Herdah, Berkarya Bersama Ditengah Covid 19; pare-pare nusantara press (2020)

http://ejournal.umm.ac.id/index.php/jppg 2723-0066 (Print) Jurnal Pendidkan, dikutip 